Australia's researchers

\section{seek a break from reform}

\section{Canberra}

THE pace of reform is causing problems in Australia's higher education system. Since the Minister for Employment, Education and Training, John Dawkins, issued a policy paper last December, institutions of higher education find they must concentrate scarce research funds in areas where they possess special expertise, and where they can serve the nation's economic needs.

The old system of distributing funds according to an institution's student enrolment and educational status has gone and, along with it, the Commonwealth Tertiary Education Commission. A new body, the National Board of Employment, Education and Training, directly answerable to Dawkins, is now responsible for giving out funds, through its subcouncil, the Australian Research Council (ARC). An increasing proportion of those research funds will be given out through competitive bidding based on an institution's "educational profile". The profile is intended to set out the institutions' strengths and explain how they can best serve national priorities. A problem is that the government has so far identified only marine science as an area of priority.

Although ARC was originally conceived of as a statutory body within the Department of Science, it will now be instrumental in carrying out Dawkins' reforms. Its newly appointed interim chairman (and, so far, sole member) is Professor Don Aitkin, a political scientist at the Australian National University. He says that to expect the government to find the extra A\$50 million which in the Australian Science and Technology Council (ASTEC)'s view the ARC needs to be effective is unrealistic as "Australia slides into debt at $\$ 1,000$ million per month".

But another of Dawkins' reforms will provide him with an opportunity to find A\$30 million a year for the next three years. The current difference in level of funding between universities and colleges of advanced education is to disappear, and the extra funds that are now provided for universities are to be put up for competitive bidding.

With himself as the only member of ARC, Aitkin is concerned that there will be delays in getting the reforms off the ground unless Dawkins appoints the rest of the council within the next few weeks. The budget is due in July and the council needs to provide guidance to institutions so grant applications can be finalized before then.

Another important question still unanthe final arbiter swered is who is to set Australia's research priorities. According to Aitkin, $\mathrm{ARC}$, as the grant-giving body, will be

Another candidate for the job is ASTEC which was established to advise the prime minister directly on matters of science, technology, and their effects on society. ASTEC is going through some changes. It has a new chairman, Professor Ray Martin, a research chemist who was vice-chancellor of Monash University in Melbourne until last year. And for the first time since its establishment, ASTEC is not working on any specific investigation for the prime minister. According to the secretary of ASTEC, Dr Greg Tegart, "Ray Martin has a clean slate". Martin wants ASTEC to play a role in setting Australia's research priorities.

Those priorities are certain to centre on aiding Australia's manufacturing industries. Department of Trade figures analysed by Tegart show that Australia lags far behind countries like Sweden and Norway in its volume of exports. With only sluggish growth expected in mineral and agricultural exports, Australia must turn to manufacturing.

Dr David Widdup, executive director of the Federation of Australian Scientific and Technological Societies (FASTS), doubts the ability of government to predict which areas of science and technology would be Australia's best bets and would prefer industry set priorities. He proposes that a one per cent levy be made on sales of manufactured goods and industry decide what research the money should be spent on. He believes the system has already worked well for many years in the coal, wool amd wheat industries.

The government hopes that Australia's largest research body, the Commonwealth Scientific and Industrial Research Organisation (CSIRO), will come to the nation's rescue as it has in the past, by acting as an engine to drive the growth in manufacturing that Australia needs.

CSIRO has just been through a major restructuring that resulted from a major report on it by ASTEC. According to CSIRO's chief executive officer, Dr Keith Boardman, restructuring was necessary to restore the balance between basic research and applied research. Basic research had been too much favoured.

But scrapping of CSIRO divisions and a shortage of funds has left morale low through much of the organization. CSIRO divisions are now expected to find 30 per cent of their budget directly

\section{Living off the Earth}

\section{Washington}

ALTHOUGH there are plenty of practical problems plaguing the US space programme, at least one US congressman believes that spiritual revitalization is also needed. To that end, Representative George Brown (Democrat, California) has introduced legislation that would establish human settlement of the space frontier as a long-range national objective, a goal he hopes will rekindle the national enthusiasm for space that helped to propel the Apollo lunar programme.

Extending human activities beyond Earth orbit has already received White House blessing in the new space policy signed by President Reagan in January (see Nature 331,550;1988). But most of the discussion about a national space policy has focused on shorter-term questions, such as whether to build the proposed permanently manned space station, or how best to reintroduce expendable launch vehicles to the US fleet.

Brown says the lack of long-range planning has contributed to the malaise that now afflicts the US space programme. The National Aeronautics and Space Administration (NASA) has begun to give some thought to returning to the Moon, or perhaps planning a manned mission that would go directly to Mars. His legislation would move such activities out of the back corridors of NASA headquarters and onto centre stage.

Some serious thought is being given to permanent communities off the Earth. Space Biospheres Ventures, a private company in Oracle, Arizona, is developing just such habitats. In January 1990, 8 people will enter Biosphere 2 , an enclosed structure covering more than two acres with a volume of some 5 million cubic feet. Inside there are a variety of biomes; a wilderness area, a tropical rainforest, a savannah, an ocean, salt and freshwater marshes and a desert.

from industry. According to Dr Graeme Caughley of the Division of Wildlife and Ecology, the division's budget has fallen 5-10 per cent in real terms each year for several years. Operating expenses cannot be cut further and staff layoffs will be the only possibility if further cuts are made. By its nature, much of the division's work has no appeal to industry, unless perhaps to the timber industry, whose money, Caughley professses, his colleagues would hesitate to accept because of a possible conflict of interests.

Boardman summed up CSIRO's position with the statement, "What we need now is 3-5 years of stability".

Charles Morgan 
The mix of ecosystems should make it possible to sustain life for two years in a totally enclosed environment. Such a project could be the prototype for artificial ecosystems on other planets.

Others have speculated on the macroeconomics of human activities off the surface of the Earth. The Space Studies Institute has considered using raw materials mined on the Moon for constructing Earth-orbiting satellites. One project of particular interest is constructing power satellites capable of converting sufficient solar energy to provide an economically viable supply of energy to Earth.

Eric Jones of Los Alamos National Laboratory has also studied how human settlements might make use of locally available resources on the Moon. Jones draws the analogy of early settlement of the American West and Australia. For these pioneers, their local environment was a rich source of raw materials, and so too could be the Moon, with its favourable gravity making transportation to Earth relatively easy.

Were it to stand alone, Brown's legislation would have little chance of passage. But Brown hopes to amend it to the NASA authorization bill. If he can infect other congressmen with his enthusiasm for settling space, NASA will have to start recruiting for settlers instead of astronauts.

Joseph Palca

\section{Conflict continues between Armenians and Azerbaijanis}

\section{London}

THE current conflicts between Soviet Armenians and Azerbaijanis over the autonomous region of Nagorno-Karabakh has highlighted one of the major faults of pre-perestroika planning; the ease with which mistakes and failures could be concealed by gross-figure 'achievements'.

Although the petition by the Armenian population of Nagorno-Karabakh to be administered from Erevan rather than Baku is also based on considerations of cultural identity, economic factors have a particular relevance. For Lenin's original decision in December 1917 was that, although not contiguous with Armenia, Nagorno-Karabakh was "irrevocably" part of Armenia. In 1923, however, the region was assigned to Azerbaijan, on the grounds that this would ensure its more rapid economic and social development. So, on 11 February 1988, when the petition was launched at a rally in Stepanakert, asking for the region to be returned to Armenia, the signatories were in effect challenging the legitimacy of the 1923 decision. They maintained that Nagorno-Karabakh was economi-

\section{Congressional roasting for NIH critics}

\section{Washington}

THE US Congress's love affair with the National Institutes of Health (NIH) reveals itself in the strangest ways. Last week, NIH director James Wyngaarden found himself under fire from Representative John Dingell, the chairman of a subcommittee that oversees NIH activities, for having yielded to arm-twisting when he downgraded the status of three of NIH's research administrators from "outstanding" to "excellent" status.

The person doing the arm-twisting, Thomas Burke, chief of stafi of the Department of Health and Human Services (HHS), was roasted by Dingell at the same congressional hearing. Burke protested that he had simply been trying to reduce the number of people with the "outstanding" rating; some HHS departments had come to contain nobody who was not "outstanding" - a strange contradiction in terms. But Dingell clearly felt that such action would damage morale at NIH.

Dingell is among the congressional supporters of NIH who are deeply concerned, as he put it, that "top-level researchers and managers no longer find the NIH an attractive place to work"'. While many at the Bethesda campus might rate NIH's charms higher, there is no doubt that the difference in pay between NIH and the universities is now perceived by Congress and Wyngaarden as a major threat to NIH's continued preeminence.

Wyngaarden produced figures showing that US medical school base salaries for department chairmen range from $\$ 109,000$ in basic science to $\$ 179,000$ in clinical science. Their counterparts at NIH receive $\$ \mathbf{8 2 , 0 0 0}$, and there are strict federal government limits on the amount of bonuses that can be paid. The biggest worry, according to Wyngaarden, is not that they will simply lose established researchers to the universities, but that they will fail to attract the brilliant young researchers needed to maintain NIH's reputation over the next 10-20 years.

NIH have suggested legislation that would create a 'senior biomedical research service', which would free federal biomedical research organization researchers from civil service pay limitations. The Office of Management and Budget has suggested going one step further and "privatizing" NIH Bethesda campus, turning it into a university or research foundation outside the government. Neither view is likely to prevail in the near future, according to HHS officials at the hearing. Instead, all parties are likely to wait for the results of a report on NIH's prospects commissioned from the Institute of Medicine and due to be completed in November. Alun Anderson cally disadvantaged in relation to the rest of Azerbaijan.

The Azerbaijan authorities organized a high-level 'round table' to refute these claims. Their deliberations were eventually reproduced in the party daily $B a$ kinskii Rabochii and indicated that the population of Nagorno-Karabakh was significantly better off in social amenities, not only than the rest of Azerbaijan, but also often Armenia, and even than the Soviet average.

Crude figures can, however, be deceptive. The table presented by Bakinskii Rabochii gives Nagorno-Karabakh the advantage over Armenia according to eight of the nine chosen indices, and over Azerbaijan as a whole according to seven indices. But a reading of the figures suggests that this is not the whole story. The excess of middle-level medical staff (Nagorno-Karabakh 122.7 per 10,000 population, Azerbaijan 93.5, Armenia 93.5) coming immediately after the figures for doctors (Nagorno-Karabakh 29.1, Azerbaijan 38.4, Armenia 86.6 per 10,000 inhabitants) suggests that extra nurses and paramedics may have been drafted in to make up for the shortage of doctors. And the figures for clubs, cinemas and libraries, more than twice the average for either of the two contending republics, may be due to duplication of language facilities.

By the time these figures appeared in print, however, experts in Moscow were speaking of "serious planning errors" regarding Nagorno-Karabakh. The $B a$ kinskii Rabochii data were "precise", it was now explained, but did not give the full picture. Higher education in the region, for example, consists of a single teachers' training institute-which, in spite of the almost 80 per cent Armenian population, offers no courses in Armenian history or geography. (Reserved places at Armenian universities have now been promised to students from Nagorno-Karabakh.) Another problem in Nagorno-Karabakh, the lack of jobs for school leavers and the consequent drift of young people from the region, seems associated with the failure of the Baku planners to ensure adequate roads, water and gas supplies to Nagorno-Karabakh, without which local agriculture and industry are unable to expand. And the lack of understanding of the culturalethnic tensions which have developed between the Armenians and Azerbaijanis in the region are yet another symptom of the Soviet Union's acute lack of people trained in demography and associated disciplines (see Nature 331, 555;1988).

Vera Rich 